\title{
Treating human autoimmune disease by depleting $B$ cells
}

\section{R J Looney}

\section{Rituximab treatment is safe and justifies continued study}

$\mathrm{T}$ he development of rituximab has raised the hope of a new therapeutic approach for autoimmune diseases. In the United Sates rituximab is approved for indolent CD20+ B cell lymphomas, and it is also being evaluated in many different types of lymphomas as well as other B cell malignancies such as Waldenström's macroglobulinaemia and chronic lymphocytic leukaemia. World wide more than 300000 patients with B cell malignancies have been treated with rituximab. ${ }^{1}$ Because rituximab is generally well tolerated and because it selectively and profoundly depletes B cells, its role in immune mediated diseases, especially autoimmunity, is now also being explored. Two articles in this issue of the Annals of the Rheumatic Diseases report the clinical use of rituximab in patients with autoimmune diseases. ${ }^{2}{ }^{3}$ The first article consists of three case reports using rituximab in three different autoimmune diseases, and the second reports a series of 22 patients with rheumatoid arthritis (RA) treated with rituximab with various combinations of glucocorticoids and cyclophosphamide. Both articles found rituximab was well tolerated, and both concluded that there might have been some therapeutic benefit.

These articles are not the first reports on the use of rituximab in autoimmunity. Indeed, the same group reporting treatment of 22 patients with RA in this issue has previously reported on five patients with RA who had prolonged remission of RA with a three week course of treatment combining high dose, daily glucocorticoids, three weekly doses of rituximab, and two doses of cyclophosphamide. ${ }^{4}$ Other groups have reported the use of rituximab in idiopathic thrombocytic purpura, autoimmune haemolytic anaemia, cold agglutinin disease, and neuropathy associated with monoclonal IgM. ${ }^{5-10}$ None of these reports was adequately controlled. Thus, additional randomised clinical trials are needed for definitive evaluation of the effectiveness of rituximab in autoimmune disorders. As these trials are being planned, it is a good time to reflect on the roles of $\mathrm{B}$ cells in autoimmune disease, on the effects of rituximab on the immune system, and on the possible effects of rituximab on autoimmune disease.

\section{WHAT ARE THE ROLES OF B CELLS IN AUTOIMMUNE DISEASE?}

$B$ cells are by definition the source of all immunoglobulins, and in this capacity they obviously have a critical role in antibody mediated autoimmunity. B cells should not, however, be viewed as passive makers of immunoglobulins, with other cells, especially $\mathrm{T}$ helper cells, making all the important decisions. B cells also have a key role in determining the responses to antigen both directly as antigen presenting cells and indirectly by influencing other antigen presenting cells such as dendritic cells.

\section{"Development of autoimmune disease may be blocked in animals deficient in B cells"}

B cell deficient mice were first produced by administration of anti- $\mu$ antibodies beginning at birth. ${ }^{11-15}$ These animals had a severe defect in $\mathrm{T}$ cell priming, as assayed by proliferative responses and delayed-type hypersensitivity when antigen was given locally in complete Freund's adjuvant. These B cell deficient mice were also resistant to certain autoimmune diseases such as experimental autoimmune encephalitis and spontaneous insulin dependent diabetes (in non-obese diabetic mice). ${ }^{16-20}$ Interestingly, immunisation with peptide rather than intact protein circumvented the need for B cells. ${ }^{21}$ Mice genetically deficient in B cells have now been produced by knocking out either the transmembrane (TM) domain of $\operatorname{IgM}(\mu \mathrm{TM})$ or the $\mathrm{J}_{\mathrm{H}}$ segment. These $\mathrm{B}$ cell deficient mice have generated controversy about the role of $\mathrm{B}$ cells in T cell responses, because in some (C57 Black/6) but not other backgrounds $\mathrm{T}$ cell responses were relatively well preserved. A recent publication has resolved some of these inconsistencies. ${ }^{22}$ In all backgrounds, including C57 Black/6, T cell responses were severely defective with low doses of protein antigens.
Moreover, responses to even high doses of protein were severely defective if mice with a C57 Black/6 background were allowed to develop normally (B cells are required for normal lymphoid node development) and then were irradiated and reconstituted with bone marrow from B cell deficient animals ( $\mu$ TM B6). Adoptive transfer of polyclonal B cells into $\mu \mathrm{TM}$ B6 reconstituted animals corrected the defect in $\mathrm{T}$ cell responses, but adoptive transfer of monoclonal B cells from an immunogenetic transgenic animal did not. These results suggest but do not prove the importance of antigenspecific $B$ cells in $\mathrm{T}$ cell responses to soluble proteins.

The development of autoimmune disease may also be blocked in animals genetically deficient in B cells. For example, in B cell deficient $\mathrm{J}_{\mathrm{H}}$ - MRL lpr + mice not only were autoantibodies completely absent but also the massive increase of $\mathrm{T}$ cells in lymphoid organs was prevented. ${ }^{23-25}$ When $\mathrm{J}_{\mathrm{H}^{-}}$MRL lpr + mice were bred to express an IgM transgene that can only be expressed as a membrane and not as a secreted protein, autoantibodies were again absent but the massive increase of $\mathrm{T}$ cells in lymphoid organs was reconstituted, indicating that B cells play a role in the $\mathrm{T}$ cell activation in this model ${ }^{26}$ Interestingly, nephritis with cellular infiltrates in the renal interstitium and vessels was seen in these animals despite the absence of autoantibodies. ${ }^{27}$ Thus, even apart from their production of autoantibodies, B cells may have an important role in autoimmunity by activating $\mathrm{T}$ cells in certain models of SLE. Experimentally induced autoimmune diseases may also fail to develop in B cell deficient micefor example, myasthenia gravis in mice immunised with acetylcholine receptor, and collagen arthritis in mice immunised with type II collagen. ${ }^{28}{ }^{29}$ In both of these models $\mathrm{T}$ cells from the immunised, B cell deficient animals respond to the immunising autoantigen, despite the absence of disease, suggesting that in these models the autoantibodies themselves may be critical. Thus, there is considerable evidence of a critical role for B cells both in normal $\mathrm{T}$ cell responses and in the induction of autoimmune disease.

A somewhat different role for B cells is the induction of autoreactive $\mathrm{T}$ cells by antigens that cross react at the $\mathrm{B}$ cell level. ${ }^{30-32}$ For example, naive mice immunised with mouse cytochrome $c$ had no T cell response, but mice previously immunised with human cytochrome $c$ and then immunised with mouse cytochrome $c$ did have a mouse cytochrome $c$-specific $\mathrm{T}$ cell response. $\mathrm{T}$ cell response to mouse cytochrome $c$ may be transferred from mice immunised with human cytochrome $c$ not by $\mathrm{T}$ cells or serum but only by B cells. In these 


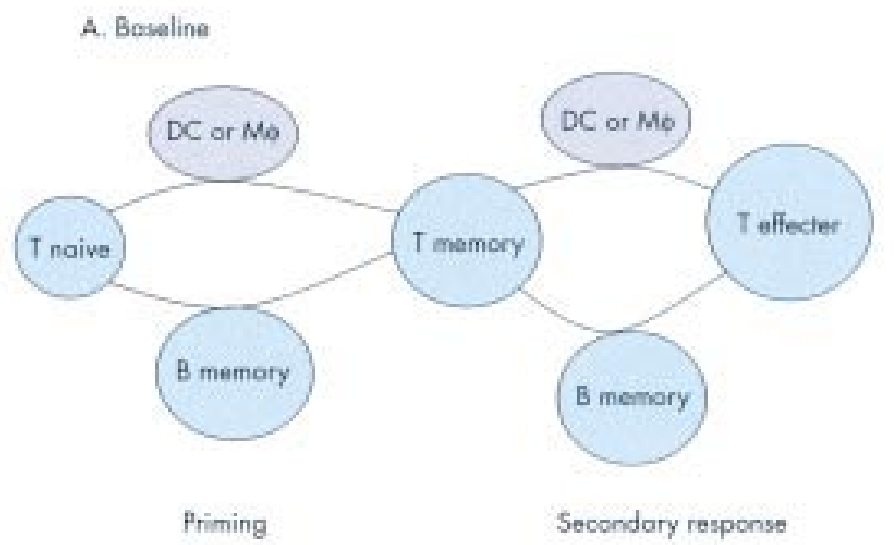

B. After treatment with rituximab

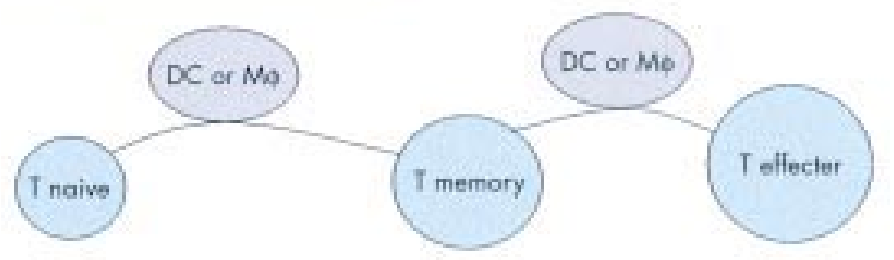

2. Memary B cells as the source of autoanhodies

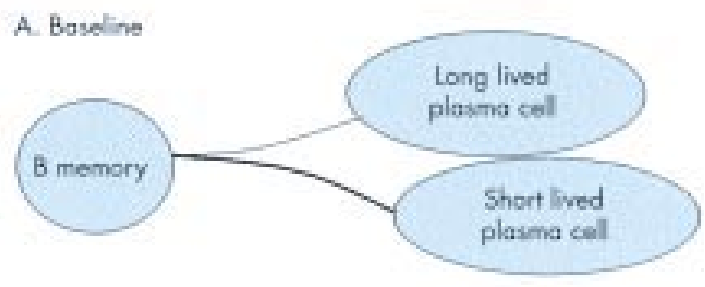

B. After treotment with rituximab

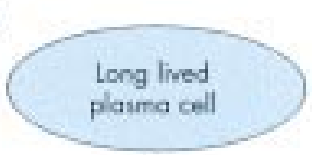

3. B cell regulation of DCs and T cels

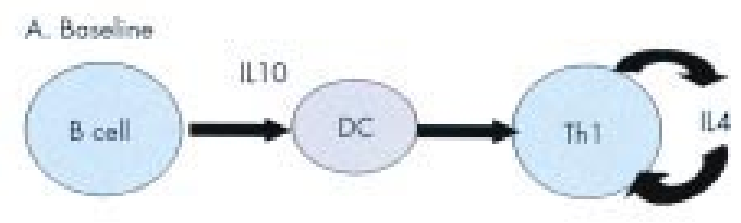

B. After treatment with rifuximab

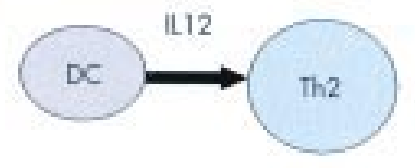

Figure 1 Possible effects of rituximab on human autoimmune disease.

experiments $\mathrm{B}$ cells from mice immunised with human cytochrome $c$ expressed surface immunoglobulins that reacted with both human and mouse cytochrome $c$. Presentation of mouse cytochrome $c$ by these self cross reactive $\mathrm{B}$ cells appears to break $\mathrm{T}$ cell tolerance. Once the autoreactive memory $\mathrm{T}$ cells are generated they recognise mouse cytochrome $c$ presented by a variety of antigen presenting cells. Similar cross reactivity at the $\mathrm{B}$ cell level may be responsible for induction of an SLE-like illness in animals immunised with peptides from Sm.

B cell deficient animals may also have altered T cell responses; these changes in $\mathrm{T}$ function may be due to changes in dendritic cells. ${ }^{33}$ For example, B cell deficient animals have an enhanced cytotoxic response against transplantable tumours. The mechanism for this enhanced response to tumours was not investigated. However, T cells from B cell deficient animals have been found to be defective in their ability to provide B cell help or to produce interleukin (IL) 4 . Dendritic cells from B cell deficient mice have enhanced production of ILl2 and preferentially induce $\mathrm{T}$ helper $\mathrm{l}$ (Thl) cells. This phenotype is similar to the phenotype of IL10 knockout mice. Splenocytes from B cell deficient mice have low levels of IL10 mRNA. Moreover, IL10 treated dendritic cells from B cell deficient mice develop the ability to induce T cell production of IL4. Thus, B cells also appear to have important immunoregulatory effects that are mediated through dendritic cells, perhaps due to B cell production of IL10. Thus, B cells may have an immunoregulatory role.

\section{WHAT ARE THE EFFECTS OF RITUXIMAB ON THE IMMUNE SYSTEM?}

Rituximab is a humanised mouse monoclonal antibody (mouse variable regions and human IgGl constant regions) directed at human CD20. ${ }^{34}$ Both mouse and human CD20 are B cell-specific membrane proteins with four transmembrane spanning domains, intracellular carboxyl and amino terminal 
domains, and a 50 amino acid loop that is extracellular. They are members of the MS4A family that includes the Fc $\gamma$ RI $\beta$ chain and in humans at least seven other expressed sequences. ${ }^{35}$ They can function as calcium channels but their physiological role is unknown. CD20 appears on B cells at the pre-B stage and disappears during differentiation to plasma cells. Thus, immature B cells and mature naive and memory B cells all express CD20. Rituximab can mediate both complement mediated cytotoxicity and antibody dependent cell mediated cytotoxicity. Moreover, cross linking CD20 on the surface of B cells using rituximab plus a secondary antibody or an Fc $\gamma \mathrm{R}$ expressing cell can result in apoptosis. Experiments in mice transplanted with human B cell tumours suggest that Fc $\gamma$ RIII is critical for B cell depletion in vivo. ${ }^{36}$ The association of improved clinical response in patients with lymphoma with the high affinity allele of FcyRIIIa suggests the importance of Fc $\gamma$ RIIIa for depletion of B cells by rituximab in humans. ${ }^{37}$ In patients with lymphoma remarkably effective and long term (6-12 months) depletion of peripheral blood B cells has been observed. ${ }^{38}$ In studies in nonhuman primates the effects of rituximab are relatively transient because of the development of an anti-rituximab immune response. ${ }^{39}$ Nevertheless, in these animals rituximab treatment immediately before immunisation completely prevented primary and secondary antibody responses, consistent with the expression of CD20 on naive and memory B cells. ${ }^{40}$ Immunoglobulin levels are generally well preserved after treatment with rituximab, presumably because of the lack of expression of CD20 on plasma cells.

Additional studies on the effects of rituximab on the normal immune system in humans are clearly needed. These should include evaluation of the extent of B cell depletion from lymphoid organs, determination of primary and memory $\mathrm{B}$ and $\mathrm{T}$ cell response after immunisation, and measurement of antibody levels and $\mathrm{T}$ cell responses to important pathogens. Consideration should also be given to strategies that might enhance the effectiveness of rituximab. For example, a prolonged course of rituximab might be given so that plasma cells producing autoantibody have an opportunity to disappear. Alternatively, rituximab might be combined with agents that target plasma cells. Thus, conventional treatment of SLE could be used to reduce autoantibody levels, and rituximab could then be introduced to eliminate memory B cells, preventing recurrence and reducing the need for more toxic drugs.

\section{WHAT ARE THE PREDICTED EFFECTS OF RITUXIMAB ON AUTOIMMUNE DISEASE?}

Based on our current knowledge can we predict the effects of rituximab on human autoimmune disease? (fig 1). The problem in extrapolating from the animal models so far available is that they are all based on B cell deficiency before the onset of autoimmunity. There are no reagents that deplete $B$ cells in adult mice to the extent that rituximab depletes B cells in humans. Rituximab given before the onset of autoimmunity, like the anti- $\mu$ antibodies in the mouse models, would probably have a very good chance of preventing certain autoimmune diseases. Of course, rituximab is being tested as a treatment for established autoimmune disease, a much more difficult task. With established disease, there will already be autoantigenspecific $\mathrm{T}$ cells (in situations where they are relevant to the immunopathogenesis of autoimmunity). Therefore, even if $\mathrm{B}$ cell presentation of autoantigen were critical for the initial sensitisation of $\mathrm{T}$ cells, once autoimmune memory $\mathrm{T}$ cells have been generated, presentation of antigen by non-B cell might be sufficient to sustain the autoimmune process. Similarly, autoantibody producing plasma cells will have already been generated, and because they do not express CD20 should not be affected by rituximab. If autoantibody producing plasma cells were long lived, then a change in autoantibody titre might not be seen during a standard course of rituximab. On the other hand, if generation of activated $\mathrm{T}$ cells required autoantigen presentation by B cells, or if autoantibody producing plasma cells had a short lifespan, then rituximab might be very effective. Unfortunately, neither the role of B cells in the continuing activation of autoimmune $\mathrm{T}$ cell nor the lifespan of autoantibody producing plasma cells is known for any human autoimmune disease. Thus, at this time it appears impossible to predict the likely efficacy of rituximab for human autoimmune diseases, and we must rely on the educated guess of the investigators. The development of a small animal model that allows relatively complete depletion of $\mathrm{B}$ cells in adult animals would be a major advance in our ability to study the role of $\mathrm{B}$ cells in established autoimmune disease. Several groups have active research programmes to develop reagents for $\mathrm{B}$ cell depletion in mice.

\section{CONCLUSION}

Based on the articles in the current issue of the Annals of the Rheumatic Diseases and previously published reports, it appears that rituximab treatment of autoimmune diseases is safe and shows enough promise to justify continued study. Its efficacy should now be determined in randomised clinical trials. These clinical trials will need to be carefully designed to take advantage of the unique effects that $\mathrm{B}$ cell depletion may have on established disease. The clinical effects of rituximab and studies of the immune system of subjects in these trials should provide invaluable insight into the role of $\mathrm{B}$ cells in human autoimmune disease.

Ann Rheum Dis 2002;61:863-866

\section{Authors' affiliations}

R J Looney, University of Rochester, Rochester, New York, USA

Dr Looney has a grant from Genentech and IDEC to study the use of rituximab in systemic lupus erythematosus (SLE). He has also served as a consultant for these companies on the use of rituximab in autoimmunity.

Correspondence to: Professor R J Looney, University of Rochester, 601 Elmwood Avenue, Rm G-6454, Rochester, NY 14642, USA; John_Looney@URMC.Rochester.edu

\section{REFERENCES}

1 Treon SP, Anderson KC. The use of rituximab in the treatment of malignant and nonmalignant plasma cell disorders [review; 49 refs]. Semin Oncol 2000;27/suppl 12):79-85.

2 Arzoo K, Sadeghi S, Liebman HA. Treatment of refractory antibody mediated autoimmune disorders with an anti-CD20 monoclonal antibody (rituximab). Ann Rheum Dis 2000;61:922-4.

3 Leandro MJ, Edwards JCW, Cambridge G. Clinical outcome in 22 patients with rheumatoid arthritis treated with $B$ lymphocyte depletion. Ann Rheum Dis 2000;61:883-8.

4 Edwards JC, Cambridge G. Sustained improvement in rheumatoid arthritis following a protocol designed to deplete $B$ lymphocytes Rheumatology (Oxford) 2001;40:205-11.

5 Levine TD. Pestronk A. IgM antibody-related polyneuropathies: B-cell depletion chemotherapy using rituximab. Neurology 1999;52:1701-4.

6 Bussel JB. Overview of idiopathic thrombocytopenic purpura: new approach to refractory patients [review; 25 refs]. Semin Oncol 2000;27(suppl 12):91-8.

7 Patel K, Berman J, Ferber A, Caro J. Refractory autoimmune thrombocytopenic purpura treatment with rituximab. Am J Hematol 2001;67:59-60.

8 Stasi R, Pagano A, Stipa E, Amadori S Rituximab chimeric anti-CD20 monoclonal antibody treatment for adults with chronic idiopathic thrombocytopenic purpura. Blood 2001:98:952-7.

9 Berentsen S, Tjonnfjord GE, Brudevold R Gjertsen BT, Langholm R, Lokkevik E, et al. Favourable response to therapy with the anti-CD20 monoclonal antibody rituximab in primary chronic cold agglutinin disease. $\mathrm{Br} J$ Haematol 2001;115:79-83.

10 Quartier P, Brethon B, Philippet $P$, Landman-Parker J, Le Deist F, Fischer A Treatment of childhood autoimmune haemolytic anaemia with rituximab. Lancet 2001;358:1511-13.

11 Ron Y, De Baetselier P, Tzehoval E, Gordon J, Feldman M, Segal S. Defective induction of antigen-reactive proliferating $T$ cells in $B$ cell-deprived mice. II. Anti-mu treatment affects the initiation and recruitment of T cells. Eur J Immunol 1983; 13:167-71.

12 Ron Y, de Baetselier P, Gordon J, Feldman M, Segal S. Impairment of antigen-specific T cell proliferative response in B cell suppressed mice. Adv Exp Med Biol 1982;49:609-15. 
13 Hayglass KT,Naides SJ, Scott CF Jr Benacerraf B, Sy MS. T cell development in B cell-deficient mice. IV. The role of $B$ cells as antigen-presenting cells in vivo. J Immunol 1986:136:823-9.

14 Ron Y, Sprent J. T cell priming in vivo: a major role for $B$ cells in presenting antigen to $\mathrm{T}$ cells in lymph nodes. J Immuno 1987; 138:2848-56

15 Janeway CA Jr, Ron J, Katz ME. The B cell is the initiating antigen-presenting cell in peripheral lymph nodes. J Immunol 1987; 138:1051-5.

16 Willenborg DO, Prowse SJ.

Immunoglobulin-deficient rats fail to develop experimental allergic encephalomyelitis. J Neuroimmunol 1983;5:99-109.

17 Gausas J, Paterson PY, Day ED, Dal Canto MC. Intact B-cell activity is essential for complete expression of experimental allergic encephalomyelitis in Lewis rats. Cell Immunol 1982;72:360-6.

18 Willenborg DO, Sjollema P, Danta G. Immunoglobulin deficient rats as donors and recipients of effector cells of allergic encephalomyelitis. J Neuroimmunol 1986; 11:93-103.

19 Myers KJ, Sprent J, Dougherty JP, Ron Y. Synergy between encephalitogenic T cells and myelin basic protein-specific antibodies in the induction of experimental autoimmune encephalomyelitis. J Neuroimmuno 1992;41:1-8.

20 Noorchashm H, Noorchashm N, Kern J, Rostami SY, Barker CF, Naii A. B-cells are required for the initiation of insulitis and sialitis in nonobese diabetic mice. Diabetes 1997;46:941-6.

21 Lyons JA, San M, Happ MP, Cross AH. B cells are critical to induction of experimental allergic encephalomyelitis by protein but not by a short encephalitogenic peptide. Eur J Immunol 1999;29:3432-9.

22 Rivera A, Chen CC, Ron N, Dougherty JP, Ron $Y$. Role of $B$ cells as antigen-presenting cells in vivo revisited: antigen-specific $B$ cells are essential for $T$ cell expansion in lymph nodes and for systemic T cell responses to low antigen concentrations. Int Immunol 2001;13:1583-93.

23 Chan OT, Madaio MP, Shlomchik M. The central and multiple roles of B cells in lupus pathogenesis [review; 188 refs]. Immunol Rev 1999;169:107-21.

24 Shlomchik MJ, Madaio MP, Ni D, Trounstein $M$, Huszar $D$. The role of $B$ cells in $\mathrm{lpr} / \mathrm{lpr}$-induced autoimmunity. J Exp Med 1994; 180:1295-306.

25 Chan O, Shlomchik M. A new role for B cells in systemic autoimmunity: $B$ cells promote spontaneous T cell activation in MRL-lpr/lp mice. J Immunol 1998;160:51-9.

26 Chan OT, Hannum LG, Haberman AM Madaio MP, Shlomchik M. A novel mouse with $B$ cells but lacking serum antibody reveals an antibody-independent role for $B$ cells in murine lupus. J Exp Med 1999; 189:163948.

27 Chan OT, Madaio MP, Shlomchik M. B cells are required for lupus nephritis in the polygenic, Fas-intact MRL model of systemic autoimmunity. J Immunol 1999; 163:3592-6.

28 Li H, Shi FD, He B, Bakheit M, Wahren B, Berglof $A$, et al. Experimental autoimmune myasthenia gravis induction in $B$ cell-deficient mice. Int Immunol 1998;10:1359-65.

29 Svensson L, Jirholt J, Holmdahl R, Jansson L. $B$ cell-deficient mice do not develop type II collagen-induced arthritis (CIA). Clin Exp Immunol 1998;111:521-6.

30 Mamula MJ, Janeway CA Jr. Do B cells drive the diversification of immune responses? Immunol Today 1993;14:151-2; discussion 153-4

31 Mamula MJ, Lin RH, Janeway CA Jr, Hardin JA. Breaking $T$ cell tolerance with foreign and self co-immunogens. A study of autoimmune $B$ and $T$ cell epitopes of cytochrome $c$. J Immunol 1992;149:789-95.

32 Lin RH, Mamula M, Hardin JA, Janeway CA Jr. Induction of autoreactive $B$ cells allows priming of autoreactive T cells. J Exp Med 1991;173:1433-9.

33 Moulin V, Andris F, Thielemans K, Maliszewski C, Urbain J, Moser M. B lymphocytes regulate dendritic cell (DC) function in vivo: increased interleukin 12 production by DCs from B cell-deficient mice results in Thelper cell type 1 deviation. J Exp Med 2000; 192:475-82

34 Sacchi S, Federico M, Dastoli G, Fiorani C Vinci G, Clo V, et al. Treatment of B-cell non-Hodgkin's lymphoma with anti CD 20 monoclonal antibody rituximab [review; 52 refs]. Crit Rev Oncol-Hematol 2001;37:13-25.

35 Liang Y, Buckley TR, Tu L, Langdon SD, Tedder TF. Structural organization of the human MS4A gene cluster on chromosome 11 q12. Immunogenetics 2001;53:357-68.

36 Clynes RA, Towers TL, Presta LG, Ravetch JV. Inhibitory Fc receptors modulate in vivo cytoxicity against tumor targets [see comments]. Nat Med 2000;6:443-6.

37 Cartron G, Dacheux L, Salles G Solal-Celigny P, Bardos P, Colomat P, Watier $H$. Therapeutic activity of humanized anti-CD20 monoclonal antibody and polymorphism in lgG Fc receptor FcyRIIla gene. Blood 2002:99:754-8

38 Maloney DG, Grillo-Lopez AJ, White CA, Bodkin D, Schilder RJ, Neidhart JA, et al. IDEC-C2B8 (rituximab) anti-CD20 monoclonal antibody therapy in patients with relapsed low-grade non-Hodgkin's lymphoma. Blood 1997;90:2188-95.

39 Reff ME, Carner K, Chambers KS, Chinn PC, Leonard JE, Raab R, et al. Depletion of B cells in vivo by a chimeric mouse human monoclonal antibody to CD20. Blood 1994:83:435-45.

40 Gonzalez-Stawinski GV, Yu PB, Love SD Parker W, Davis RD Jr. Hapten-induced primary and memory humoral responses are inhibited by the infusion of anti-CD20 monoclonal antibody (IDEC-C2B8, rituximab). Clin Immunol 2001;98:175-9. 